\title{
BALTISAKSLASE ROMAAN
}

\section{Teos ja autor}

\author{
LJUBOV KISSELJOVA
}

$J$ utt on Eestist pärit parun Karl Georg Woldemar Friedrich von Rosenist (1800-1860). Väga auväärse, X sajandisse ulatuva suguvõsaga baltisakslane, kelle esivanemad elasid Eesti-ja Liivimaal juba alates XIII sajandist (Otšerk 1876; ka emapoolse suguvõsa - von Taubede - genealoogia on vähemalt sama esinduslik), valis endale ebatavalise elutee. ${ }^{1}$ Ta sündis oma emale kuuluvas Rickholtzi mõisas (tänapäeval Riguldi, Haapsalu lähedal) (Lexikon 1970: 645). Kodukeeleks oli muidugi saksa, kuid ka prantsuse keelt valdas noor parun vabalt. Lapsepõlvest alates oli Rosen huvitatud antiikkultuurist (ta oskas suurepäraselt kreeka ja ladina keelt), eriti antiikaja luulest, unistas ka ise poeediks saamisest ja kirjutas oma esimesed luuletused ladina keeles. Vaevalt aimas ta neil aastatel, et tulevikus on tema kirjanduslik karjäär seotud keelega, mida ta tookord veel üldse ei osanud.

Vene keelt - aga selles keeles on kirjutatud suurem osa tema teostest - hakkas Rosen õppima alles 19-aastaselt, kui ta astus sõjaväeteenistusse Jelizavetgradi husaaripolgus ja sattus otse Vene provintsi, Saraatovi kubermangu. Oma autobiograafias tunnistas ta: „Meie kõige tuntumad kirjamehed, kellega ma hiljem tihedalt suhtlesin, on väljendanud mulle oma imestust selle üle, kuidas mina, kes ma suurte raskustega omandasin sõjaväeteenistuses vene keele, olen suutnud nii sügavalt mõista vene rahva hinge, millest annavad tunnistust mu esimesed draamad. Vastus ei ole raske. Olles mitte ainult lahti rebitud, vaid tervenisti ära lõigatud saksa vaimsusest ja saksa elust, ja veel niisuguses vanuses, kui süda püüdles elu ja maailma poole, pidin ma leppima vene rahvaga. Minu esimesed armuavaldused leidsid väljenduse vene keeles. Tihti pidin koos husaaridega viibima stepikülas, saja versta kaugusel polgu staabist, ja võtma osa külanooruse idüllilistest mängudest, kuulama jutuvestjate ja laulikute iidseid lugusid ja laule, osalema rahvaliku elu kõigis külgedes, nii et märkamatult elasin ma kogu hingest sisse rahva vaimsusesse. Võin öelda täiesti kindlalt - ja minu arvamus on erapooletu -, et ma pole oma elus kohanud midagi kütkestavamat ja poeetilisemat, kui seda on vene rahva elu, nagu elatakse kaugel postimaanteest, otse looduslikus seisundis" (Rosen 1841: V-VI).

Oma esimesed venekeelsed teosed avaldas Rosen juba 1825. aastal. 1820. aastate lõpus astus ta vene kirjandusse kui luuletaja, tõlkija, kriitik ja kirjastaja. Nagu kirjutab tema loomingu kõige tähelepanelikum uurija Vadim Vatsuro: „...kirjandusringkondades oli suhtumine Rosenisse heakskiitev, kuid osaliselt ka üleolev, nagu andekasse, kuid siiski muukeelsesse poeeti” (Vatsuro 2004: 770). Tutvudes 1829. aastal Puškiniga, sattus Rosen tema

${ }^{1}$ Eluloolisi andmeid on säilinud vähe, sest pärast Roseni surma hävitas vend tema arhiivi. Peamised andmed paruni elu kohta on võetud lühikesest autobiograafiast, mille ta kirjutas oma näidendi „Ivan III tütar” saksakeelse trüki eessõnana (Rosen 1841). 
huviorbiiti. Puškin ergutas tema kirjanduslikku tegevust, avaldas tema teoseid oma väljaannetes, oli ka ise osaline Roseni almanahhides „Tsarskoje Selo” („Царское село”) ja „Altsiona” („Альциона”). ${ }^{2}$ Rosen oli tuntud ka vene kirjanduse tutvustajana saksa keeles. Ta avaldas oma tõlkeid ja artikleid vene kirjandusest baltisaksa väljaannetes, eriti Tallinnas ilmunud Esthonas (Issakov 1971), aastaraamatus „Dorpater Jahrbücher für Litteratur, Statistik und Kunst, besonders Russlands" jm. ${ }^{3}$ Tartus avaldas parun 1833 . aastal artikli Puškini „Boriss Godunovist” koos teose käsikirja põhjal tehtud tõlkega ühest tragöödia stseenist, mis oli vene väljaandest välja jäänud ja jõudis saksa lugejani seega varem kui venelasteni.

1830. aastate keskpaiku saabub Roseni kirjandusliku karjääri õitseng. Temast saab tuntud dramaturg, tema ajaloolised draamad „Venemaa ja Batory” („Россия и Баторий”, teise pealkirjaga „Pihkva piiramine” - „Осада Пскова”, 1832-1833), „Pjotr Basmanov”, „Ivan III tütar” („Дочь Иоанна III”, 1835) andsid oma panuse vene rahvusliku draama kujunemisse (Vatsuro 2004; Kisseljova 2013, 2015). Roseni kõige tuntum draamateos on kahtlemata 1836. aastal Mihhail Glinka ooperile kirjutatud libreto „Elu tsaari eest” („Жизь за царя”). Isekas ja kergestihaavuv Rosen oli väga solvunud, et kogu au esimese vene rahvusliku ooperi loomise eest läks ainult heliloojale. Kuid kõigele vaatamata on just see teos elanud meie ajani ja taastatuna pärast 1930. aastate ümbertegemisi (ooper sai siis ka uue pealkirja „Ivan Sussanin”) lavastatakse seda nüüd maailma suurimatel ooperilavadel just nimelt Roseni libreto järgi.

1830. aastate keskel venepärastab Rosen ka oma eesnime, temast saab Jegor Fjodorovitš, ja see žest oli tema jaoks põhimõttelise tähendusega. Oma mälestustes Puškinist on ta kirjutanud: „Kuni noorukiaastateni ei tundnud ma ei vene keelt ega vene vaimu ja alles parimas eas omandasin vene keele ja hakkasin armastama vene $\mathrm{rah}$ va st, ning sellega sain õiguse kuuluda selle rahva hulka" (Rosen 1974: 275). Roseni eesnime Georg lihtrahvalik vorm Jegor kindlustas tema silmis seda õigust, kuna ta tundis end vene rahvusliku ideoloogia ühe loojana. Kuid Rosen ei unustanud noorpõlve Läänemere ääres ja kasutas oma loomingus ka meenutusi kodukandist.

1831. aastal ilmus almanahhis „Altsiona” parun Roseni väike romaan (või jutustus) „Constantin Loeven. (Minu mälestustest)” (vt Rosen 1831). ${ }^{4}$ Mind huvitab see teos praegu „Liivimaa teema” (st Balti provintside ja nende elanike) originaalse interpretatsiooni tõttu vene kirjanduses. Romaan on jäänud välja uurijate vaateväljast, isegi kõnealuse teema parim uurija ja tundja Sergei Issakov ei arvestanud seda oma klassikalises töös (Issakov 1960).

Sergei Issakovi kandidaadiväitekiri „Liivimaa teemast vene kirjanduses 1820.-1830. aastatel”, kus on detailselt loetletud kõik kõnealusel teemal kirjutatud teosed, vabastab mind kohustusest süveneda detailidesse. Tegelikult on tendents täiesti ilmselge. Sellele, kes on heitnud pilgu Aleksandr Bestuževi 1820. aastate teostesse, tulevad kohe meelde hirmsad baltisaksa aadlimehed ja nende keskaegsed lossid, kus toimusid kohutavad kuriteod. Tuletame kas või meelde julma magistrit Winno von Rorbachi „Võnnu lossist” („Замок

\footnotetext{
${ }^{2}$ Vene Altsiona on Plejaadide tähtkuju kõige eredam täht, mille eesti vaste on Alküoone (tõlkija märkus).

${ }^{3}$ Issakovi artiklis on toodud Roseni Esthonas avaldatud tõlgete täielik loend. Vt ka Issakov 1960.

${ }^{4}$ Otsustades tsensori loa kuupäeva põhjal - 17. X 1830, langeb teksti kirjutamine ilmselt sellesse aastasse.
} 
Венден”), salakavalat Romuald von Meyd ja Arensburgi salakohtu liikmeid „Vastseliina lossist” („Замок Нейгаузен”), metsikut röövlit parun Bruno von Eisenit „Eiseni lossist” („Замок Эйзен”), keda autor ise on nimetanud „looduse loodud koletisteks". Nagu on iseloomulik romantilistele kurjategijatele, on nad eemaletõukavad kõiges: nad rõhuvad ja piinavad eestlastest talupoegi, veedavad oma elupäevi mõttetutes lõbustustes, reedavad sõpru, röövivad kaunitare, et neid rüvetada, hukutavad oma ümberkaudseid. Isegi nende antagonistid (juhul, kui nad ei ole venelased!), kuigi nad ise ei ole kurjategijad, on kergeusklikud (nagu näiteks Ewald von Nordeck „Vastseliina lossis”), alluvad Bestuževi määratluse kohaselt barbaarse aja vaimule ja sooritavad kättemaksust juhindudes ka ise kuritegusid (nagu Wigbert von Serrat „Vastseliina lossis” või Reginald „Eiseni lossis”).

Kuid pöörame tähelepanu sellele, et Bestužev ja teisedki autorid pajatavad keskajast, mida nad ise nimetavad barbaarseks. Oma kaasaega, kui Balti kubermangud olid juba hulk aega olnud Vene impeeriumi koosseisus, need romantilised jutustused ei käsitlenud. Sellest ajast kõnelesid 1810. ja 1820. aastatel vähesed reisikirjad ja publitsistika. Neis tekstides kirjeldati avameelselt ja õiglaselt eesti ja läti talupoegade rõhumist, mis liitus üldise orjuse hukkamõistmise kontekstiga ja diskussioonidega talurahvaküsimuse üle Venemaal. Samal ajal kõneldi neissamades reisimärkmetes ka „tumedast” keskajast ja nii jäi Balti provintside üldist kuvandit ning järelikult ka Balti mõisnike kuvandit ümbritsema vene lugeja jaoks negatiivne oreool. Sellisel taustal võib pidada novaatorlikuks parun Roseni valikut, kes lõi kaasaegse Balti aadliku Constantin Loeveni positiivse kangelase kuju.

Loomulikult pidi selleks, et niisugust valikut õigustada, olema hea põhjendus. Ja Rosen on selles osas leidlik: ta on teinud oma kangelasest Kreeka ülestõusu osalise. Kreeklaste vabadusvõitlus oli XIX sajandi alguses üks tulisemaid ja toona arutati seda kogu Euroopas. 1810. aastate lõpus ja 1820. aastatel kirjutasid Venemaal Kreeka küsimusest kõik ajakirjad: selleteemalisi artikleid ilmus sõna otseses mõttes igas ajakirjanumbris. Avaldati ka mahukaid raamatuid nn Kreeka küsimuse ajaloo kohta (Soutzo 1829; Leake 1826; La Motte-Fouqué 1822; Pouqueville 1824a) ja mitmetes Euroopa keeltes kõlas kaastundlikke üleskutseid kreeklaste toetuseks (Chateaubriand 1825; Constant 1825; Martsella 1826; Pouqueville 1824b). Paljudes Euroopa riikides tegutsesid hellenofiilide ringid, mille liikmed kogusid mitmesuguseid vahendeid ülestõusnute jaoks, aga sageli läksid ka ise vabatahtlikena türklaste vastu võitlema. Loomulikult oli kõigi, ka Roseni, huultel Byroni, 1810.-1820. aastate „mõtteilma valitseja” nimi, kes ohverdas oma varanduse ülestõusu toetamiseks ja sõitis ka ise Balkanile võitlema. Byron suri malaariasse Mesolóngis kreeka väepealiku Aléxandros Mavrokordátose juures ja seda võeti nagu hukkumist Kreeka vabaduse eest.

Venemaal oli olukord segane nagu tavaliselt. Üks esimesi kreeklaste salaorganisatsioone, mis tegeles Türgi-vastase ülestõusu ettevalmistamisega Philiki Etaireia (Sõprade Ühing) -, asutati Odessas 1814. aastal (Arš 1965; Malõhh jt 1988). Juba alates XVIII sajandi teisest poolest sekkus Vene impeerium aktiivselt Balkani probleemidesse ja innustas Balkani rahvaste võitlust Türgi vastu. Pärast Katariina II „Kreeka projekti” ebaõnnestumist võttis Venemaa vastu rohkesti kreeka põgenikke, kes moodustasid maa lõunaosas

\footnotetext{
${ }^{5} \mathrm{Vt}$ „Rorbachi veri niisutas tapalava - kuritegu viidi täide!” (Bestužev 1958: 45).
} 
terved kreeka kolooniad (sel viisil asutati tänapäevane Odessa 1794. aastal). Kreeka kaupmehed seadsid end sisse Nežinis, Taganrogis, Moskvas, neile anti ka teatud privileegid. Kreeklasi võeti ka Vene sõjaväkke armee ja laevastiku teenistusse. Määrates Joannis Kapodistriase Venemaa välisministriks, millisele ametikohale ta jäi ka pärast ülestõusu algust (Arš 1976), andis keiser Aleksander I aluse arvata, et Venemaa toetab kreeklaste väljaastumist. Kuid kui algas relvastatud ülestõus Valahhias (võib öelda, et peaaegu impeeriumi territooriumil), kuhu suundusid võitlema paljud kreeklased, ka Vene armee ohvitserid (muuhulgas vennad Ypsilantid), samuti rumeenlased (Tudor Vladimirescu), siis keelas keiser ära mitte ainult selles ülestõusus osalemise, vaid ka haavatute ja põgenike vastuvõtu Venemaa territooriumil. Kreeklaste „Püha korpus" Alexandros Ypsilanti juhtimisel löödi puruks lahingus Drăgăşani all 6. juunil 1821. Seejärel purustas ülestõusnud 19. juunil Skuljanõ all neist kümme korda suurem türklaste sõjavägi - ja seda otse Vene armee silmade all, kes peatus Pruti vasakkaldal ja sõna otseses mõttes ei tohtinud appi minna.

Parun Rosen tegi oma väljamõeldud kangelastest Constantin Loevenist ja tema sõbrast Leonidas Kondroriottist romaanis üsna üksikasjalikult kirja pandud sündmuste osalised. Kui kreeklase Leonidase suhtes on autor täielikult järginud ajaloolist reaalsust, sest „Pühas korpuses” võitlesid Odessast pärit kreeklased, siis baltlase Loeveni puhul lasi ta fantaasial vabalt lennata. Kõige hoolikamate teadusuuringute kohaselt osalesid „Philiki Etaireia” ridades ainult kreeklased (Arš 1970). Kuid autorile olid ühtaegu vajalikud nii kreeka ülestõus kui ka baltisakslasest kangelane.

Kreeka teema kasutamine asetas romaani „Constantin Loeven” ajajärgu kõige aktuaalsema žanri - ajaloolise romaani - konteksti: just aastad 1829-1830 olid selle žanri sünniaeg Venemaal. Kuid erinevalt Mihhail Zagoskini „Juri Miloslavskist” (1829) ja Faddei Bulgarini „Dmitri Isehakanust” („Дмитрий Самозванец”, 1830), mis käsitlesid Venemaa segaduste aega, valis Rosen aktuaalse kaasaegse ajaloo sündmustest jutustava süžee. Seega oli ta uuenduslik kahe tollal populaarse žanri taustal: pidades silmas nii romantilisi „Liivimaa jutustusi” (Roseni baltisakslasest kangelane ei ole kurjategija, vaid keerulise ja imetabase siseilmaga kaasaegne inimene, vabadusvõitleja) kui ka ajaloolist romaani.

On huvitav märkida, et Roseni romaani arvustanud kriitikud isegi ei puudutanud kreeka teemat. Kõige rohkem arutati teose stiili ja selle mitmesuguseid romantilisi pöördeid. Nikolai Polevoi, kes oli varem korduvalt Roseni teoseid heatahtlikult arvustanud, oli seekord karm: „Kui „Constantin Loevenit” ei oleks kirjutanud juba nimekas autor, oleks põhjust arvata, et see on mõne saksa tudengi kirjatöö, kes on arutult lugenud Hoffmanni, Zschokket ja Klaurenit.” Polevoi süüdistas autorit ka „labaste germanismide” ja kunstliku vene keele kasutamises (Polevoi 1831).

Severnaja Ptšela suhtus „Constantin Loevenisse” armulikumalt: „Soovitaksime seda näitemängu julgelt kõigile meie lugejannadele, kui me ei oleks kindlad, et meie aja plastilised Phryned sunnivad neid punastama - ja mitte kadedusest [Phrynest tuleb pikemalt juttu allpool - L. K.]. Huvipakkuvat on selles jutustuses piisavalt; tegelaste karakterid on antud väljapeetult, kahju ainult, et stiil on mõnevõrra ülespuhutud." Siinkohal ei ole retsensiooni autor Mihhail Jakovlev keeldunud naudingust tsiteerida mõningaid Roseni pärle: „Jelena läks külalisele vastu, avas talle oma embuste taeva ja kandis talle ette 
nektarikarika, huultel lõhnavad suudlused”, „Pisarad, mis olid peatunud ta palgetel, kõnelesid liigutavat keelt ennastsalgava südame leegitsevast valust. Armas, piinarikas pisarake! Sa langed Jumala enda kätele”, „Süda, segaduses nagu ohvrituvi, mis uputatakse pulmaveini” (Jakovlev 1831). Õigluse mõttes tuleb märkida, et autori stiil ei ole mitte alati selline. Võrdluseks toome mõne sedalaadi tsitaadi ka Bestuževilt. „Võnnu loss”: „Sa oled teatanud oma otsuse ja põlastanud jumala kohtupidamist õnnistatud relvaga,” ütles Serrat, ja viimane praeguse hetkeni süütu südametunnistuse pisar langes kinžalli mõrvarlikule terale” (Bestužev 1958: 42). „Vastseliina loss”: „...aga vend ja sõber, ma tahan värskendada oma hinge, jutustades sulle... Vennad ... istusid paju alla, mis rippus rohelise võlvina kalda kohal, ja käsikäes, pilgud teineteise silmadesse suunatud, rääkisid nad lähedastest ja kodumaast ja kõik hingetundmused ja kõik südamekired peegeldusid otsekohe Vseslavi kirkal palgel...." (Bestužev 1958: 82).

Seega ei ole „Constantin Loeveni” stiili puhul tegu mitte niivõrd ebaõnnestunud „rosenismidega”, vaid pigem tolleaegse vene romantilise proosa tüüpiliste stampidega. Siiski ei hoiatanud kriitikud Rosenit asjatult hüperboolidest ja ülespuhutud metafooridest küllastunud stiili eest: parun, kes ei mõistnud, et sellised väljendid mõjuvad vene keeles koomiliselt, oli oma tekstid nendega kohati lausa üle külvanud, pidades neid romantilise stiili lahutamatuks koostisosaks.

Kuid see, et kriitika Kreeka teema täielikult maha vaikis, tekitab paratamatult küsimusi. Sel ajal kui Rosen kirjutas oma romaani, oli kreeklaste võitlus Türgi ülemvõimu vastu võidukalt lõppenud. 1830. aasta veebruaris tunnustasid Euroopa riigid ja ka Venemaa Kreeka iseseisvust. Siiski oli kaks asjaolu, mis muutsid Kreeka teema delikaatseks: toonased lugejad teadsid hästi, et otsustaval momendil ülestõusu alguses reetis Venemaa ilmselgelt kreeklased, ja seda ei soovitud meenutada. Lisaks sellele tõlgendati vene 1820 . aastate luules Kreeka teemat kui võitlust türanni vastu (vt Iljinskaja 2010) ilmsete allusioonidega Venemaa ja Vene isevalitsuse kohta. Ilmselt osaliselt just sellepärast väheneb Kreeka teema vene luules pärast 1825 . aastat järkjärgult, kuigi ei kao päriselt.

1828. aastal kavatses Puškin kirjutada poeemi röövel Kirgealist, kes võttis osa Ypsilanti ülestõusust. Nagu teada, oli poeet Kišinjovis viibimise ajal paljude kreeklaste võitlusega seotud sündmuste vahetuks tunnistajaks ja elas kreeklastele tuliselt kaasa. Ta tundis paljusid liikumise tegelasi, sealhulgas ka Alexandros Ypsilantit, ja üldse kogu Kišinjovi kreeka kolooniat, elas kibedalt üle kreeklaste lüüasaamist ja Vene valitsuse taandumist, ülestõusu osaliste hukkumist otse Vene sõjaväelaste silme all. Juba siis hakkas Puškin koguma ajaloolisi materjale kreeklaste ülestõusu kohta (Puškin 1977-1979, VIII: 88). Ka pärast sõitu Odessasse jälgis ta tähelepanelikult Balkani sündmusi (andmete kokkuvõtet vt Svirin 1935). Kreeklaste võitlus kütkestas teda ka edaspidi: värvika näitena rahvuslikust liikumisest koos selle romantiliste illusioonide ja reaalsete vastuoludega, samuti osalistevaheliste konfliktidega (sellest kirjutab ka Rosen „Constantin Loevenis”).

Poeem Kirgealist jäi loomata, kuid 1834. aastal kirjutas Puškin samanimelise jutustuse (Puškin 1977-1979, VI: 238-243). „Kirgealis” lahendab Puškin keeruka kunstilise ülesande, mis on oluline kogu tema 1830. aastate proosa seisukohast. Romantilise röövli süžee koos kõigi röövliteema atribuutidega 
(verised kuriteod, õudused, vangipõli, pettus, põgenemine vanglast - omamoodi uus variatsioon poeedi enda „Vendadele-röövlitele” („Братья разбойники”, 1822) ja Byroni „Chilloni vangile” (1816)) sobitub täielikult Walter Scotti romaanide traditsiooni, seda käsitletakse kaasaegset materjali kasutades ja armuintriigi mängu toomata. Meie ees on peaaegu dokumentaaljutustus, mis tugineb noore ametniku (kellel on nii mõistust kui ka südant) usaldusväärsele tunnistusele ning samuti autori enda isiklikele mälestustele Kišinjovi eluolu kohta. Puškini stiil erineb järsult „šoti võluri” lillelisest paljusõnalisusest ja muidugi ka 1820. aastate vene romantiliste jutustuste stiilist - see on tõeline „alasti proosa”.

Rosen tutvus Puškiniga just sel ajal, kui ta kavandas oma romaani. Pole välistatud, et kirjutama valmistudes küsitles ta poeeti ülestõusuga seotud sündmuste ja inimeste kohta 1820. aastate algusest, samuti uuris tema muljeid Odessa kohta, kus toimub Roseni romaani tegevus. Parun ei olnud seal kunagi viibinud, kuid Puškin oli seal elanud üle aasta.

„Constantin Loeven” avaldati mitte ainult enne Puškini „Kirgealit”, vaid ka enne „Lasku”, mille finaalis on öeldud: „Räägitakse, et Alexandros Ypsilanti mässu ajal juhtis Silvio hetairistide salka ja sai surma lahingus Skuljanõ all” (Puškin 1977-1979, VI: 69). Loomulikult ei jõudnud Rosen ligilähedalegi Puškini proosa tasemele, kuigi tema romaani kavand oli ilmselgelt ambitsioonikas ja Puškini (kuid mitte ainult Puškini) mõjud olid jõudnud ka temani.

Roseni positsioon vene kirjanduses oli kahetine. Ühelt poolt oli tema, baltisakslane, kes oli vene keele omandanud alles täiskasvanuna, teadlikult valinud ve ne kirjaniku tee. Teiselt poolt jätkas ta kirjutamist saksa keeles ja püüdis end kirjutada ka saksa (eelkõige baltisaksa) kirjanduslikku konteksti. Vene kirjanduses tundis Rosen end siiski eurooplasena, ${ }^{6}$ sellepärast ta mitte ainult et valis oma romaanile mastaapse teema Vene ja Euroopa ajaloo piirimailt, vaid ka vastava kangelase, kelle kaudu ta demonstreeris nii impeeriumi euroopaliku provintsi kultuurilist erinevust kui ka oma vaimustust vene lihtrahva ja Venemaa üle. Seda vaimustust väljendas autor ka oma teistes tekstides, neis juba iseenda nimel kõneldes. Kuid juhime tähelepanu, et selline vaade paljastas temas pigem välismaalase, kes vaatas kõike otsekui kõrvalt. Romaanis tugevdab seda topeltvaadet romaani teise kangelase - kreeklase Leonidase positsioon, kes oli, nagu ka Loeven, Vene alam ja Vene ohvitser. Ta tundis Venemaa üle samuti vaimustust, kuid oli pühendanud oma elu eranditult Kreekale.

Romaani tegevus algab Tallinnas. Juba esimestes peatükkides toob Rosen sisse kreeka teema, valmistades lugejaid varakult ette põhisüžee arenguks. Constantin Loeven on klassikalise antiigi asjatundja, ta toetab Aristippose hedonistlikku kontseptsiooni - mõistlikku naudingut, mis on ühendatud oskusega valitseda oma kirgi. Ta korraldab Tallinnas Eleusise pidustustele analoo-

${ }^{6}$ Rosen ei olnud impeeriumi perioodil vene kirjanduses kaugeltki ainus baltisaksa päritolu kirjanik (suurele faktimaterjalile toetudes on seda kirjandust analüüsinud oma suurepärases artiklis Kirill Rogov, 1998). Roseni kaasaegsete hulgas on mitmed Puškini lütseumikaaslased: Anton von Delwig, Wilhelm von Küchelbecker. Roseni positsiooni ei tee keerukaks mitte ainult tema vene keele eripära (mis oli küll grammatiliselt õige, kuid mõnevõrra kunstlik ja stiliseeritud), tema saksa aktsent ega isegi mitte püüd olla oma loomingus kakskeelne. Probleem oli tema samaaegsetes pretensioonides olla juhtiv rahvuslik dramaturg ja osaleda vene rahvusideoloogia ülesehitamisel ning tema pisut kummastavas vaates Venemaale ja vene kultuurile. 
gilise peo, täpsemalt - valib välja ühe Eleusise müsteeriumi momendi. Nimelt selle, kus Praxitelese modell, kuulus hetäär Phryne läks alasti, lahtiste juustega läbi rahvahulga ja astus merre, et osutada au jumalatele. Constantin valis tänaval jalutavate Tallinna kodanike hulgast välja kauni tütarlapse sümboolse nimega Gretchen, kes oli pagari tütar, ja veenis teda lõppude lõpuks mängima Phryne rolli: „Ta suutis võita tema sõpruse, ... ja lõpuks, et saavutada oma veider eesmärk, ... püüdis ta anda talle edasi oma mõtteviisi, st kreekalikku arusaamist vabadusest sugudevahelises läbikäimises. „Olla kõrgema klassi hetäär,” lausus Constantin tütarlapsele, „ei tähenda loomupärase graatsia ja kaasasündinud ilutunde solvamist. Näed, siin on Wielandi Aristippos: selles raamatus on Laisi tegelaskujus kujutatud hetääri ideaali: tunnista ausalt, et ta on armsam kõigist meie häbelikest kaunitaridest"” (Rosen 1831: 4-5). Ja kuigi tütarlaps „sai asjast aru”, oli ta siiski kohmetunud ja pigem valmis tegema salapattu, anduma Constantinile öö varjus, kuid mees nõudis temalt täielikku vabadust ja lõpuks saavutas selle, mida soovis.

Pidustuse jaoks valiti välja sobiv koht püha Birgitta kloostri varemete läheduses. Autori plaani kohaselt pidid tema ja ta sõbrad vaikides vaatama, kuidas alasti kaunitar astub merre, ja nautima tema naiselike vormide täiuslikkust: „Puhta ilu vaatlemine ei sünnita kunagi kiimalisi mõtteid ... see kahjustaks ilu nautimist!” (Rosen 1831: 7). „Imeline vaatemäng”, mida näitas Constantin Loeven oma sõpradele, lõppes järgmiselt: „Varsti nägime meie poole kõndivat tütarlast, kelles otsekohe tunti ära meie kaunitar... Pilk oli langetatud, ere puna mängles ta põskedel, tasaste, ebakindlate sammudega lähenes ta meile. [---] Lastes valla pika rikkaliku patsi, hakkas ta lahti riietuma: see enese järkjärguline paljastamine vaimustas meid: kõigi meie hing oli silmades. Langes viimane riideese ja pimestavas säras, vaid ebakindlalt varjavad käharad teda katmas, suundus meie alasti armastusjumalanna vaikselt merre ja Constantin hüüatas: „Siin ta on - Phryne Eleusises!” Heidame nüüd graatsiate katte varjama seda stseeni" (Rosen 1831: 6-7).

Mitte põhjuseta ei nimetanud Jakovlev Severnaja Ptšela arvustuses, et see stseen pani punastama (Jakovlev 1831). Meie ees on tõepoolest XIX sajandi alguse vene kirjanduse jaoks ebatavaliselt julge stseen, mida ei saa nimetada just süütuks. ${ }^{7}$ Ka romaanis endas osutusid selle eksperimendi tagajärjed kangelanna jaoks, keda mitte põhjuseta ei nimetatud Goethe teosest pärineva nimega, kurbadeks: eksperiment sai avalikuks ja Gretcheni reputatsioon oli rikutud. Esialgu suhtus ta sellesse kergemeelselt ja temast saigi hetäär selle sõna täies tähenduses: ,...ta andus ainult tema armastuse valinud noormeestele" (Rosen 1831: 100-101). Seejärel ta kahetses, kuid see ei parandanud tema mainet. Naastes Tallinna pärast osalemist Kreeka ülestõusus, mõistis Constantin, et on Gretcheni ees süüdi, otsustas oma süü lunastada ja pakkus talle isegi oma kätt. Naine keeldus ,austusest rahva arvamuse vastu ja eelkõige mehe haige ema vastu" (Rosen 1831: 102). Siis andis Loeven tütarlapsele rikkaliku kaasavara ja pani ta mehele.

\footnotetext{
${ }^{7}$ Autor aimas seda ette ja üritas stseeni kindlustada põhjaliku kommentaariga. Constantini sõnade kohaselt: „Kujutame ette, et me nägime Praxitelese loomingut, mis avas meie hingele pääsu täiuslike vormide heledasse maailma ... ilu nägemine ilma katteta, mis täitis mu pea mõtetega, täidab mu harda armastusega Jumala kõige kaunima loomingu vastu!" ja üks tema sõpradest vastab: „Sinu jutt lõhnab millegipärast naturaalse dialektika järele ... hoia oma hinge saatana eest!" (Rosen 1974: 7-8.)
} 
Loeveni romantilised elueksperimendid ei lõppenud sellega. Peatselt korraldas ta teise pidustuse - seekord keskaja rüütlielust pärineva -, taastades oma mõisas prantsuse rooside külapeo. Romaanis on antud lühike ülevaade selle traditsiooni ajaloost (Rosen 1831: 11), mille on sõnastanud juba VI sajandil püha Médard Salencyst: „See on armas liigutav pidu niisuguse neitsi ülistamiseks ja kroonimiseks, kes paistab teiste hulgas silma oma naiseliku vooruslikkusega" (Rosen 1831: 9). Peo lõpus autasustatakse vooruslikku tütarlast roosipärjaga (ning lisaks sellele ka rahakotiga, mida parun ei nimeta).

Rooside pidu tähistatakse Lõuna-Prantsusmaal praeguseni. Sellest, et vastavat pidu on peetud Roseni lapsepõlves ka Miitavis, annab tunnistust prantsuse kunstniku Jean-Charles Tardieu maal „Louis XVIII kroonib rooside neitsit Miitavis”. Pilt on muidugi lavastuslik, maalitud Bourbonide restauratsiooni ajal. Kuid pole välistatud, et Miitavis tõepoolest korraldati neid pidustusi ajal, kui seal viibis tulevase kuninga Louis XVIII õukond, ja jutud neist pidudest võisid jõuda ka Eestimaale noore Roseni kõrvu. Romaanis kroonib Constantin roosipärjaga oma noore sugulase Liina. Sealjuures rõhutab autor, et Loeven ei tundnud ei tema ega ka Gretcheni vastu mingeid armutundeid - see oli kummardus puhta ilu ees. ${ }^{8}$ Autor ei nimeta oma kangelast asjatult „klassikaliseks võrukaelaks", kes ühendab moraalse vabamõtlemise klassikalise armastusega kaunite vormide vastu. Ilmselgelt on tegu eksperimentaalse konstrueeritud käitumise kujutamisega, mille algimpulss pärineb kirjandusest.

Ühte raamatuallikat nimetab ka Rosen ise, see on Christoph Martin Wielandi romaan „Aristippos ja mõned tema kaasaegsed” („Aristipp und einige seiner Zeitgenossen”, 1800-1802), kus jutlustatakse hedonismi ideaali - meelelisi naudinguid, mida on õilistanud mõistus ja esteetiline tunne. Kuid mõiste „võrukael”, üks libertiini kinnismääratlusi (Dmitrijeva 2013), paneb mõtlema sellele, kas ei peitu siin vihje veel ühele traditsioonile - prantsuse libertiinliku romaani traditsioonile.

Jekaterina Dmitrijeva osundas mulle üht XVIII sajandi teksti, kus räägitakse fête de la Rosière'ist (rooside peost Salencys). See on Mirabeau kuulus libertiinlik romaan „Minu pöördumine”. Teoses külastab kangelane, kõrgest soost libertiin külapidu: „Selle vaatepildi, süütuse ja lihtsameelsuse kehastuse liigutav lihtsus sünnitab minusuguste libertiinide hinges meeleliigutust, mida on raske tagasi hoida.... [---] Niipea, kui ma nägin teda, kellele peol ulatati roos, tekkis mul otsekohe soov noppida tema õielehti. See oli kuueteistkümne aastane külaneiu, naiivne, tundlik ja väga ilus. Õppisin koos temaga tundma armastuse kõiki vilju" (Mirabeau 2013: 396).

Muidugi ei ole parun Roseni „Constantin Loeven” libertiinlik romaan, kuigi seal on vihje ka sellele, et vaene Gretchen-Phryne sattus lõpuks ikkagi Constantini embusse ja noormehe mõtiskluste põhiliseks objektiks oli ka meeleline armastus. Võib-olla on tegu kõhklustega või väga osava mänguga kahe traditsiooni - saksa ja prantsuse - vahel. Igal juhul on meie ees romantismiperioodile väga iseloomulik situatsioon, mida Juri Lotman on kirjeldanud Puškini Tatjana näitel, kui kirjandusest saab kirjandusliku tegelase käitumise mudel (Lotman 1975: 48). Rosen lisab veel ühe täiendava käigu: meie ees on

\footnotetext{
${ }^{8}$ Selle episoodi juurde naaseb Rosen romaani lõpus ja kirjeldab, kuidas üksildased Liina ja Constantin „teatud vaeslapsetundega” meenutavad „unustamatut õhtut” (Rosen 1831: 104).
} 
kirjandusliku mudeli teatraliseerimine (Constantin korraldab „etendusi”, kus ta ei ole mitte ainult osaline, vaid ka sündmuse lavastaja).

Pärast Tallinna saadab Rosen etteaimatavalt oma kangelase Tartusse, kuid ülikoolis Loevenile ei meeldi: „Tema vaba vaim ei harjunud poolharitlastest noormeeste pedantsusega: nende lapselikud tülid, noorte kukkede kaklused, siivutud tembud peletasid endast eemale õrna ja tundelise ilu austaja" (Rosen 1831: 14-15). Kuigi Constantini iseloomustus - püüda ise kujundada oma saatust - on peaaegu Nikolai Jazõkovi luuletuse „Tartu” tsitaat, suhtus baltisakslane Rosen, erinevalt vene poeedist, buršikommetesse täiesti negatiivselt ja tema Tartu tõlgendus on kaugel Jazõkovi tudengiluuletuste vaimust (see on veel üks meie autori märgiline erinevus ajastu kirjanduslikust kontekstist).

Edasi saadab autor Constantini husaaripolku ja kasutab oma kangelase teekonda Venemaa sisekubermangudes, et tema suu läbi avaldada kaks olulist deklaratsiooni. Esimene puudutab Constantini, tõeliselt romantilise kangelase, iseloomu: „Loodan, et mitte miski maailmas ei saavuta kunagi alandavat võimu minu kindlameelse hinge üle: see, kes on alati iseendale kindel, on oma saatuse valitseja!" kirjutab ta isale Eestisse (Rosen 1831: 16). Teine mõtteavaldus on seotud arutlusega vene rahva üle, kusjuures kangelane apelleerib „Venemaad hästi tundva ränduri arvamusele” (Rosen 1831: 16). Kuna nii välismaiseid kui ka vene rahvusest ränduritest kirjamehi, kes alates Radištševist on konstrueerinud vene rahvuslikku iseloomu küüdimeeste ja postipoiste põhjal (nimetades neid „vene rahva õiteks”), oli rohkesti, ei tasu hakata siin oletama, kas Rosen on silmas pidanud mõnd konkreetset kirjanikku. Igal juhul on ta oma kangelase suhu pannud järgmised sõnad: „Milline imeline rahvas, uljas, lõbus, heasüdamlik isegi oma petutempudes, - õitsva tervisega jõulised iludused... Kui palju luulet ja elavust on nende südikas eluolus: istub kutsaripukki, end lohakalt kiigutades, laseb vilet ja kannustab harjunud hüüdega hobuseid tagant, nähvab nuudiga: vanker sööstab noolena edasi; veniva häälega laulab ta kurblikku laulu, ja väikese lisaraha eest on nõus laulma kogu teekonna. Kuulan heameelega neid laule, nad puudutavad midagi südames" (Rosen 1831: 16-17). Järgneb arutlus postipoiste vagadusest: iga kiriku ees paljastavad nad pea. Seejärel jutustab Constantin oma kirjas isale anekdoodi sellest, kuidas üks küüdimees lunis rikastelt ratsanikelt „kümnekopikalist" vodka jaoks pärast seda, kui ta oli neilt saanud juba sada rubla. Kangelane küsis oma küüdimehelt, kas niisugune asi on võimalik. „Isegi väga on!” vastas mees. „Tal oli kahju vahetada peeneks nii suurt rahatähte, aga juua oli ju vaja!" (Rosen 1831: 18). Kogu positiivse tooni juures tajub baltisakslasest kangelane (nagu ka teose autor) sellist kelmustükki ehtsa vene eksootikana, millesarnasega nad oma kodus ei olnud varem kokku puutunud.

Romaani põhisündmused hakkavad arenema pärast seda, kui Loeveni mõtteilma valitsejaks saab tema polgukaaslane, salapärane ja mõistatuslik kreeklane Leonidas, kes hoidub kõrvale husaaripidudest ja püüab juhtida kergemeelset Constantini tema tõelise elukutsumuse juurde: „Saagu sinust mõogavend, Kristuse rüütel, mine võitle püha Päästja Usu eest” (Rosen 1831: 32). ${ }^{9}$ Leonidas kutsus endaga kaasa ka sõpra, rääkides talle Alexandros Ypsilanti kavatsustest. Siingi ei saa Rosen hakkama ilma vaimustunud monarhistlike

\footnotetext{
${ }^{9}$ On iseloomulik, et usulised erinevused (kreeklane Leonidas on õigeusklik, baltisakslane Constantin peaks olema luterlane) ei huvita ei tegelasi ega ka autorit.
} 
avaldusteta. Leonidas võrdleb õnnetu, pašadest türannide julma ikke all vaevleva Kreeka saatust õnneliku Venemaa omaga, kus valitseb seaduslikkus ja keiser, kelle „õlad on võimsad nagu Atlasel, kes on oma kanda võtnud Püha Venemaa tohutu seadustiku, ja võib-olla veedab ka oma öötunde keiserlikes mõtisklustes ja muredes oma rahva heaolu pärast. Tema rahvas ei ole ainult kristlased! Ka moslemid on tema lapsed ja keiserlik päike saadab kõigile võrdselt oma headtegevaid kiiri. Oh, Loeven! Kui minu Kreekale langeks osaks sinu Eestimaa kaunis saatus, kui minu kodumaa oleks Vene riigi kaitsva tiiva all, siis ei tunneks minu Kreeka nagu ka sinu Eesti vaenlase tuld ja mõõka!" (Rosen 1831: 30-31.)

Raske öelda, kas ka Rosen ise mõtles samamoodi või mitte. Ta teadis ju suurepäraselt, kui inetut rolli oli mänginud ülistatud keiser Aleksander Onnistatu kreeklaste ja Kreeka ülestõusu saatuses, ${ }^{10}$ teadis ka seda, et Balti provintsides ei pidanud paljud „Vene riigi kaitsva tiiva all olemist” sugugi positiivseks, kuid ideoloogina toetas ta tingimusteta monarhistlikke ja imperiaalseid positsioone ning arendas neid oma loomingus.

Edasi areneb Roseni romaani süžee järgmiselt. Kangelased lähevad erru ja sõidavad Odessasse (linna ei ole küll nimetatud, kuid seda on kerge aimata - just seal tegutses Philiki Etaireia keskus). Siin, Kondroriottide kodus, armub Constantin Leonidase imekaunisse õesse Helenasse. Ja siin saab alguse viimane elueksperiment, mille otsustab läbi viia väsimatu ja romantiline Loeven. Pärast Leonidase hukkumist Drăgăşani lahingus ja pärast haavatasaamist Kreekas naaseb Constantin Kondroriottide majja. Ta on kauni Helena peigmees, kõik viitab õnnelikule abielule. Kuid siin keeldub Constantin kõigi üldiseks imestuseks pruudist ja loovutab ta oma sõbrale Jevgeni Veljaminskile, kes on tütarlapsesse armunud. Ühtlasi veenab ta Helenat, et neiu saab Jevgeniga abielludes hoopis onnelikumaks kui temaga. Nagu alati, suudab Constantin naist - seekord palavalt armastatut - veenda oma mõtte õigsuses. Vastuseks tema leegitsevale monoloogile vastab Helena: „Ma ei mõista sind, kuid allun sinu tahtele kui minust parema olendi tahtele, kellele olen valmis ohverdama oma elu - ja veel hoopis rohkem kui elu. [---] Ja niisuguses olukorras ei saa ebatavalise inimese mõrsja käituda nagu teised, tavalised naised!" (Rosen 1831: 78.) Kuid peatselt kahetseb Constantin oma ettepanekut, ta saab aru, et „pettis oma südant mõistuslike sofismidega” (Rosen 1831: 96) ja ei arvestanud oma võimalustega. Kui ta naaseb juba abielus Helena koju ja võtab sülle tema tütre, mõistab ta täiel määral, millest on end ilma jätnud (Rosen 1831: 106). Helena palub tal lahkuda ja mitte segada tema pererahu (Rosen 1831: 110-111).

Oletan siinkohal, et romaani süžee sellises käänakus võis transformeeritud kujul kajastuda lugu Vassili Žukovski elust. Poeet oli sunnitud loobuma palavalt armastatud naisest Maria Protassovast, kes oli tema poolnõbu, ja nõustuma, et naine abiellub Tartu ülikooli professori, suurepärase kirurgi ja muusiku Johann Christian Moieriga. Rosen oli Žukovskiga hästi tuttav. Luuletaja korraldas varanduseta ja inimestega halvasti läbi saavale parunile, kelle sõjaväeline karjäär polnud just eriti õnnestunud, ka töökoha troonipärija, tulevase keisri Aleksander II erasekretärina. Žukovski omalt poolt ai-

${ }^{10} \mathrm{Ei}$ ole välistatud, et otsekui vastukaaluks sellele asjaolule ongi keisrit ülistatud, ei ole juhuslik, et tema rolli Euroopa vabastamisel meenutab just kreeklasest kangelane. 
tas korduvalt lahendada Roseni kirjanduslikke probleeme. Just Žukovski oli see, kes tegi Mihhail Glinkale ettepaneku, et ooperi „Elu tsaari eest” libreto võiks kirjutada Rosen. Muidugi, Maria Protassova ja Žukovski armastuse loost tollal avalikult eriti ei räägitud, kuid mingid kajastused sellest jõudsid siiski mitte ainult poeedi isiklike sõpradeni, vaid ka lugejateni. Täiesti vabalt võis Rosen pidada Maria lugu silmas oma romaani Eestist pärit romantilise kangelase kuvandi loomisel. Eestis päädis ju ka „esimese vene romantiku” nagu on nimetatud Žukovskit - eludraama finaal.

„Constantin Loevenis" loobub Rosen täiesti romantikute vaimus happy end'ist: romaan lõpeb sellega, et kangelane naaseb Tallinna ja elab seal nukras üksilduses. ${ }^{11}$ Huvitav on sealjuures märkida, et selline finaal tähistab ühtaegu kangelase romantiliste eksperimentide krahhi. Jutustaja lohutab Constantini peaaegu Puškini sõnadega: „Ebatavaline inimene ei saa olla õnnelik tavalisel viisil. See kibe kogemus veenis sind pühas tões, et südame jaoks on olemas ainult üks õnn: see, mille on saavutanud miljonid oma tavalise elu tavalisel rajal $^{12}$ - sina küpsed niisugust õnne nautima nukrusevines!" (Rosen 1831: 111-112.) Rosen on siin tundlikult tabanud ära kirjanduses juba alanud romantiliste käitumismudelite ümbermõtestamise.

Kuid isiklikus elus osutus Rosen parandamatuks romantikuks. 1840. aastate alguses abiellus ta lihtsat päritolu tütarlapsega. See kohutav mesallianss vapustas sedavõrd kuulsast suguvõsast sugulasi, et nad ei soovinud säilitada tulevaste põlvede jaoks isegi abikaasa nime. ${ }^{13}$ Sugulaste ostrakism langes kokku kirjandussituatsiooni muutumisega Venemaal. Suri Puškin, keda Rosen jumaldas ja kes oli teda alati toetanud; esile kerkisid uued nimed ja uued autoriteedid. Järk-järgult jääb õukonna teenistusest lahkunud parun eemale ka kõrgetest kirjandusringkondadest, muutudes kirjanduslikuks päevatööliseks, kes pidi teenima elatisraha ajakirjadele kirjutades ning oli sunnitud nõustuma igasuguste töödega. Rosen kaotas kontakti kirjanduseluga, pidas näiteks Gogoli loomingut vene kirjanduse languse kõige viimaseks astmeks. Ta elas erakuna Peterburi äärelinnas, väikeses majakeses Viiburi poole peal (Ussov 1882: 122). Oma viimasel eluaastal püüdis parun Rosen pääseda tööle tsensuurikomiteesse (ja ta määrati sinna vähem kui kuu aega enne surma), kuid

${ }^{11}$ Romaani finaalis on kirjeldatud Loeveni jõudmist Tallinna, nagu võib aru saada, läbi Lasnamäe, mis tõenäoliselt põhineb autori isiklikel muljetel: „Ta peatus naaberkünkal ja heitis pilgu iidsele kodulinnale, kus kõrgusid sajanditevanused müürid ning värviliste lippude ja vimplitega kaunistatud mastide mets. Juhtus sedagi, et kolm kõige kõrgemat kirikutorni kõrgusid oma tippudes taevani. Aga üht - kõige kõrgemat! - nende hulgas enam ei ole! Ta kujutas ette Tallinna Oleviste kiriku kohutavat ja suurejoonelist langemist leekides [1820. aasta tulekahjus $-L$. K.], kirik jäi siis ilma oma kõige tähtsamast kaunistusest; samuti mõtles ta oma perekonnapeata - hiljuti surnud isata - jäänud perele. Rängas mõtiskelus sidus ta need kaks sündmust, ja linna sisenedes tundus talle, et kodulinn oli kuidagi haiglaselt kokku surunud oma majad, järsud, kõrged kodukotused" (Rosen 1831: 99-100).

${ }_{12}$ Kirjas Nikolai Krivtsovile 10. veebruarist 1831 on Puškin, parafraseerides Chateaubriand'i, väljendanud enda jaoks olulist mõtet, mida ta on erinevates sõnastustes korranud oma hilisemal eluperioodil: „õnne võib leida vaid sissetallatud radadelt”: „Minu noorus möödus lärmakalt ja viljatult. Siiani elasin ma teistmoodi, kui elatakse tavaliselt. Õnne mul ei olnud. Il n'est de bonheur que dans les voies communes. Olen juba üle kolmekümne aasta vana. Kolmekümneaastaselt inimesed tavaliselt abielluvad - teen nüüd nii, nagu teised inimesed ja tõenäoliselt ei kahetse seda" (Puškin 1977-1979, X: 264). Chateaubriand'i romaani „René”, millest pärinevat tsitaati Puškin siin parafraseerib, oli Rosen loomulikult lugenud.

13 „Baltisaksa biograafilises leksikonis” on teda nimetatud N. N. (sks Wirtschafterin) (Lexikon 1970: 645). 
kirjanikule ja tsensorile Ivan Gontšarovile jättis ta segase inimese mulje, nii et oma soovitust paruni teenistussevõtmiseks Gontšarov ei kirjutanud (vt Delo).

Parun Roseni elu lõpp oli tõeliselt traagiline. Selle kohta leidub nappe andmeid minu leitud arhiividokumendis: paruni naissugulase palve, mis oli saadetud pärast tema surma Aleksander II-le (vt Dokladnaja zapiska). Paruness Nadežda Rosen palus, et keiser tasuks lahkunu võlad, mis ulatusid 1200 hõberublani, ja et tema noorim tütar paigutataks „ühte tütarlaste õppeasutusse". Ühtlasi teatas ta mõned andmed lahkunu perekonna kohta: Roseni abikaasa oli surnud seitse aastat enne mehe lahkumist, jättes lese koos kuue lapsega. Kolm neist surid ootamatult kaks päeva enne isa surma. Kolm vanemat (18-aastane Pavel, 16-aastane Anna ja 9-aastane Vera) jäid ilma elatusvahenditest ja isegi kodumajast, sest nagu võib aru saada palvekirjast, oli parun ilma jäänud ka oma majast. Palvekirjale on 10. märtsil 1860. aastal kirjutatud positiivne resolutsioon, võlg on makstud ja Vera Rosen on paigutatud õppeasutusse „kabineti, st keisri arvel”. Seega saab välja rehkendada, et Rosen võis abielluda umbes 1841. aastal (teistest paberitest selgub, et just sel ajal ta „vahetas korterit”), et tema naine (kelle nime dokumendis ei nimetata) suri umbes 1853. aastal, seega kestis nende abielu umbes 12 aastat. Me ei tea, kas ta oli õnnelik, jääb ainult seda loota. Igal juhul näitas parun ennast mitte ainult aumehena (kes ei soovinud elada ebaseaduslikult madalamast soost armastatuga), vaid ka kindlameelse inimesena, kes - nagu ka tema kangelane Constantin Loeven - jäi endale alati truuks.

Artikkel on valminud projekti IUT34-30 „Tõlkeideoloogia ja ideoloogia tôlkimine: kultuuridünaamika mehhanismid Eestis vene ja nõukogude võimu tingimustes 19.-20. sajandil” raamides.

Venekeelsest käsikirjast tõlkinud MALL JÕGI

\section{Arhiivimaterjalid}

Delo = Дело о назначении на должность цензора Петербургского цензурного Комитета барона Е. Ф. Розена. - РГИА (Российский государственный исторический архив). Ф. 772. Оп. 1. № 4878.

Dokladnaja zapiska = Докладная записка от вдовы Ротмистра Баронессы Надежды Розен 4го Марта 1860го года. - РГИА. Ф. 472. Оп. 32. Ед. хр. 1587. А. 1-1 pöördel.

\section{Kirjandus}

Ar š 1965 = Григорий Арш, Тайное общество „Филики Этерия”. Из истории борьбы Греции за свержение османского ига. Москва: Наука.

Arš 1970 = Григорий Арш, Этеристское движение в России: Освободительная борьба греческого народа в начале XIX в. и русско-греческие связи. Москва: Наука.

Ar š 1976 = Григорий Арш, И. Каподистрия и греческое национально-освободительное движение 1809-1822 гг. Москва: Наука. 
B estuž ev 1958 = Александр Бестужев, Сочинения. В 2-х томах. 1. kd. Москва: Гослитиздат.

Ch a t e a u bri a nd, François-René de 1825. Note sur la Grèce par Chateaubriand. Paris.

Constant, Benjamin 1825. Appel aux nations chrétiennes en faveur des Grecs. Paris: Treuttel et Würtz.

Dmitrijeva 2013 = Екатерина Дмитриева, Французский либертинаж и его русские отголоски. - Мишель Делон, Искусство жить дибертена. Французская либертинская проза XVIII века. Москва: Новое литературное обозрение.

Iljinskaja 2010 = Софья Ильинская, Русские поэты о греческой революции 1821 года. - http://www.ellada-russia.ru/magazine/45/article/157 (30. XI 2015).

Is s a k ov 1960 = Сергей Исаков, О ливонской теме в русской литературе 18201830-х годов. - Ученые записки Тартуского гос. ун-та. Вып. 98. (Труды по русской и славянской филологии, III.) Тарту.

I s s a k ov 1971 = Сергей Исаков, Журналы „Esthona” (1828-1830) и „Der Refraktor" (1836-1837) как пропагандисты русской литературы. - Ученые записки Тартуского гос. ун-та. Вып. 266. (Труды по русской и славянской филологии, XVIII.) Тарту.

Jakovlev 1831 = Михайл Яковлев, [Roseni teose arvustus]. - Северная Пчела, 5. I, lk 1 .

Kis s elj ov a 2013 = Дюбовь Киселева, Эстляндец барон Е. Ф. Розен - борец за русскую народность. - (Не)музыкальноеприношение, или Allegro affettuoso. Сборник статей к 65-летию Бориса Ароновича Каца. Санкт-Петербург: Издательство Европейского университета в Санкт-Петербурге, lk 242-256.

K i s s elj o v a 2015 = Пюбовь Киселева, О неожиданной попытке найти „русскую Иоанну д’Арк". - Русско-французский разговорник, или / ou Les Causeries du 7 Septembre. Сборник статей в честь Веры Аркадьевны Мильчиной. Москва: Новое литературное обозрение, $1 \mathrm{k}$ 51-60.

La Motte-Fouqué 1822 = Friedrich Heinrich de La Motte, Baron Fouqué, Betrachtungen über Türken, Griechen und Türkenkrieg. Berlin: Maurersche Buchhandlung.

Leake, William Martin 1826. A Historical Outline of the Greek Revolution. London: J. Murray.

Lexikon 1970 = Deutsch-baltisches biographisches Lexikon. 1710-1960. KölnWien: Böhlau.

Lotman 1975 = Юрий Лотман, Роман в стихах Пушкина „Евгений Онегин”. Спецкурс: Вводные лекции в изучение текста. Тарту: Тартуский государственный университет.

Malõhh jt 1988 = А. Малых, Т. Король, А. Нирша, Музей „Филики Этерия”. Путеводитель. Одесса: Маяк.

Martsella 1826 = Стефан Марцелла, Оправдание греков. Сочиненное К. А. Степаном Марцеллой и изданное им в пользу сирот и вдов греков, пожертвовавших жизнью за Веру и Отечество. Санкт-Петербург.

Mirabeau 2013 = Рикети Оноре Габриель, граф де Мирабо, Мое обращение [Благородный либертен]. - Мишель Делон, Искусство жить либертена. Французская либертинская проза XVIII века. Москва: Новое дитературное обозрение. 
O t š e r k 1876 = Очерк фамильной истории Баронов фон Розен из родовых домов Рооп, Гохрозен, Шёнангрен или Розенгоф, Райскум, Моян и пр. 992-1876. Составил Барон Андрей Евг. Розен. Санкт-Петербург.

Polevoi 1831 = Николай Полевой, [Roseni teose arvustus]. - Московский Телеграф, kd 37, nr 2, lk 250.

P o u qu eville, François-Charles-Hugues-Laurent 1824a. Histoire de la Régénération de la Grèce ... (1740-1824). Kd 1-4. Paris.

P o u qu evill e 1824b = Франсуа Пуквиль, Падение Хиоса. Санкт-Петербург (Сын Отечества ümbertrükk).

P ušk in 1977-1979 = Александр Пушкин, Полное собрание сочинений. В 10 т. Денинград: Наука.

Rogov, Kirill 1998. Russische Patrioten deutscher Abstammung. - Deutsche und Deutschland aus russischer Sicht. West-Östliche Spiegelungen Reihe B. Bd. 3. 19. Jahrhundert: Von der Jahrhundertwende bis zu den Reformen Alexanders II. München: Wilhelm Fink Verlag, lk 551-604.

Rosen 1831 = Егор Розен, Константин Иевен (Из моих записок). - Альциона. Альманах. На 1831 год. Издан Бароном Розеном. Санкт-Петербург.

Rosen, Karl Georg Woldemar Friedrich von 1841. Vorwort. - Die Tochter Joann's III. Trauerspiel in fünf Aufzügen von Baron Georg Rosen. Aus dem Russischen überesst von dem Verfasser. St. Petersburg: Carl Kray.

Rosen 1974 = Егор Розен, Из статьи „Ссылка на мертвых”. - А. С. Пушкин в воспоминаниях современников. В 2-х томах. 2. kd. Москва: Художественная литература.

S o ut z o, Alexandre 1829. Histoire de la révolution grecque. Paris: F. Didot.

Svir in 1935 = Н. Свирин, Пушкин и греческое восстание. - Знамя, nr 11.

U s s o v 1882 = Паве $\lambda$ Усов, Из моих воспоминаний. - Исторический вестник, nr 1.

V atsur o 2004 = Вадим Вацуро, Розен Егор Федорович. - В. Вацуро, Избранные труды. Москва: Языки славянской культуры.

\section{A Baltic German novel and its author}

Keywords: Baltic theme in Russian literature, biography of a Baltic German author, Greek War of Independence, poetics of a historical novel

The article discusses the Russian historical novel „Constantin Loeven (From my memoirs)" (1831) by Baron Karl Georg Woldemar Friedrich von Rosen (1800-1860), who was born in Estonia. Rosen's literary activities started from writing poetry in Latin, of which no example has survived. He used German to publish criticism and translations, but most of his oeuvre is in Russian. He started learning Russian at the age of 19 . Since 1825 he published in Russian, as his ambition was to become not only a Russian author, but also a Russian national ideologist. So he wrote some plays on themes of Russian history and a libretto for the first Russian national opera „A life for the Tzar”. 
The article analyses the innovative qualities. of Rosen's novel. The scene is laid in Estonia, southern Russia, and Greece. The protagonist participates in the Greek War of Independence. The Greek theme enables „Constantin Loeven” to be classified as a historical novel, which was the most topical genre of the time. Unlike in earlier Russian literature Rosen's romantic hero of Baltic German origin is not a gloomy criminal, but rather a modern man with a complex and strange mindset, a freedom fighter. The character owes to the German sentimentalist and romanticist tradition, as well as to the French libertine novel. In addition, the article specifies on some biographical details of baron Rosen.

Ljubov Kisseljova (b. 1950), PhD, University of Tartu, Ordinary Professor of Russian Literature, Head of the Department of Slavic Studies, ljubov.kisseljova@ut.ee 